\title{
H3.3 K27M Mutation
}

National Cancer Institute

\section{Source}

National Cancer Institute. H3.3 K27M Mutation. NCI Thesaurus. Code C148096.

A change in the amino acid residue at position 27 in histone $\mathrm{H} 3.3$ protein where lysine has been replaced by methionine. 